\title{
ANGULASI GIGI PASCA PERAWATAN ORTODONTI DENGAN PENCABUTAN DAN TANPA PENCABUTAN (Kajian Foto Rontgen Panoramik di Klinik Ortodonti FKG UI)
}

\author{
Safra Mauna,* Maria Purbiati, ${ }^{* *}$ Krisnawati ** \\ * Peserta PDGS Ortodonti FKG Universitas Indonesia tahun 2003 \\ ** Staf Pengajar Departemen Ortodonti FKG Universitas Indonesia
}

\begin{abstract}
At the end of treatment with extraction, it is often found root paralleling problem on upper second insicive, lower premolar and adjacent teeth of extraction. This caused by failure of angulation correction on finishing stage. Objective : To describe whether any differences in angulation of teeth after treatment with extraction and without extraction of patients treated in Orthodontic Clinic, RSGM FKGUI. Material and methods : The angulation measurement is done by using Ursi methode on panoramic radigraphic. Result : Based on independent t test analysis, there were a significant differences $(p<0.05)$ between tooth angulation after orthodontic treatment with extraction and without extraction on upper right second premolar and upper left canine, also on lower right canine and lower left second premolar, whereas there are no difference. Conclusion : It appeared that, tooth angulation after orthodontic treatment has a significant differences between extraction case and non extraction case (adjacent teeth of extraction). Panoramic radiograph required before finishing stage to evaluate tooth angulation and root parallelism for increase stability after orthodontic treatment.
\end{abstract}

Keywords: teeth angulation, orthodontic treatment, extraction, non extraction

\section{Pendahuluan}

Perawatan ortodonti bertujuan untuk menciptakan keseimbangan antara hubungan oklusal gigi geligi, estetik wajah serta stabilitas hasil perawatan. Umumnya tujuan terhadap estetika wajah dan hubungan oklusal gigi geligi dapat tercapai, tetapi stabilitas hasil perawatan sampai sekarang masih menjadi permasalahan yang perlu diperhatikan. ${ }^{1}$
Blake dan kawan-kawan (1998)
menyatakan salah satu faktor yang
mempengaruhi stabilitas hasil perawatan adalah
kesejajaran akar. ${ }^{2}$ Untuk mendapatkan hasil
perawatan yang stabil diperlukan angulasi gigi
yang baik sehingga dapat mendistribusikan
gaya oklusal secara proporsional pada tiap titik
kontak gigi. ${ }^{3}$ Nanda (1993) menyimpulkan
bahwa ada 10 kriteria yang harus dipenuhi 
sebelum retensi, salah satunya adalah kesejajaran akar pada daerah dekat tempat pencabutan. $^{4}$

Menurut Nanda (2005), pada hasil akhir perawatan kasus dengan tindakan pencabutan, sering kali ditemukan masalah pada kesejajaran akar pada insisif kedua atas, premolar bawah dan gigi yang berdekatan dengan tempat ekstraksi. Hal ini merupakan manifestasi yang sering terjadi akibat kegagalan memperbaiki angulasi gigi pada tahap finishing. ${ }^{5}$ Selain itu penutupan ruang ekstraksi secara ortodonti lebih mudah terbuka kembali atau relaps jika akar gigi yang berdekatan tidak sejajar, sehingga hasil yang didapat tidak stabil. ${ }^{3}$

Andrews (1972) melakukan penelitian terhadap 120 model gigi dengan oklusi normal yang belum pernah dirawat ortodonti. Berdasarkan hasil penelitiannya tersebut ditemukan enam kunci oklusi normal. Salah satu dari keenam kunci oklusi normal Andrews adalah angulasi mahkota. ${ }^{6}$ Ursi dan kawankawan (1990) melakukan penelitian menggunakan radiografi panoramik untuk menilai angulasi gigi normal. ${ }^{3}$ Kemudian Wijayani (1998) melakukan penelitian di Klinik Ortodonti RSGM FKG UI mengenai nilai angulasi gigi dengan oklusi normal. ${ }^{7}$

Sejauh pengetahuan penulis belum pernah ada penelitian yang membedakan kesejajaran gigi pasca perawatan ortodonti yang dirawat dengan tindakan pencabutan dan tanpa pencabutan. Padahal tindakan pencabutan lebih banyak dilakukan daripada tanpa pencabutan pada perawatan ortodonti di Klinik Ortodonti RSGM FKG U.I. Hal ini disebabkan karena umumnya kasus-kasus ortodonti adalah gigi protrusif dan berjejal. ${ }^{8}$ Frekuensi pencabutan gigi yang dilakukan pada perawatan ortodonti pada tahun 1995 di Klinik Ortodonti RSGM FKG UI sebesar $51,7 \%{ }^{8}$ Vaden dan Kiser tahun 1996 menemukan frekuensi pencabutan sebesar $60,4 \%$ dari seluruh kasus ortodonti yang di rawat, dengan pencabutan gigi premolar pertama sebesar $49,2 \% .^{9} \quad$ Pencabutan gigi premolar pertama lebih sering dilakukan karena lokasinya yang relatif dekat dengan regio anterior, sehingga koreksi di anterior dapat segera diatasi. Pencabutan gigi premolar pertama juga memudahkan gigi kaninus bergeser ke arah distal menempati posisi premolar pertama yang telah dicabut. ${ }^{10}$

Ortodontis perlu memperhatikan angulasi gigi pada tahap rencana perawatan, saat pemasangan alat dan tahap akhir perawatan ortodonti. Pemeriksaan angulasi gigi dilakukan melalui radiografi panoramik untuk menilai kesejajaran akar. ${ }^{10}$ Hal-hal yang mempengaruhi angulasi gigi antara lain adalah jenis braket, posisi braket dan pergerakan gigi. ${ }^{11,12,13}$

Jenis pergerakan gigi yang dibutuhkan dalam penutupan ruangan ekstraksi juga mempengaruhi angulasi gigi pasca perawatan ortodonti. Gigi dengan inklinasi mahkota tipping ke distal, memerlukan gerak root movement untuk dapat menegakkan akarnya, sedangkan gigi dengan inklinasi mahkota tipping ke mesial memerlukan jenis pergerakan controlled tipping (gambar 1). Pada gigi kaninus dengan inklinasi aksial yang tegak, gaya ke distal juga akan menyebabkan gerak mahkota semakin tipping dan akar ke arah mesial sehingga diperlukan pergerakan translasi. $^{14}$
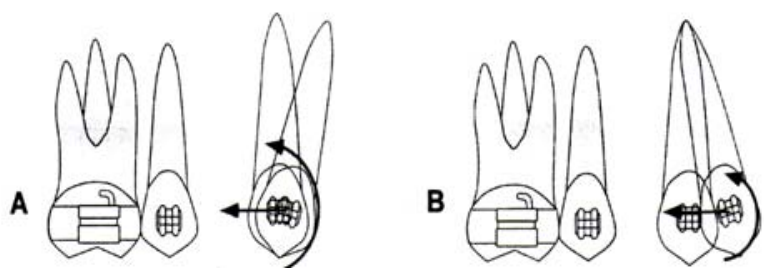

Gambar 1. Jenis pergerakan gigi yang diperlukan sewaktu retraksi. A. Root movement untuk gigi dengan inklinasi awal mahkota tipping ke distal. B. Controlled tipping untuk gigi dengan inklinasi awal mahkota tipping ke mesial (Diambil dari Nanda ${ }^{14}$ )

Radiografi panoramik merupakan alat diagnostik yang sangat berguna. Jika radiografi panoramik dilakukan sebelum dilakukan pelepasan braket, maka perubahan angulasi gigi yang diinginkan dapat dengan mudah dilakukan. $^{3}$ Paatero (1949) pertama kali menemukan teknik pantomography yang merupakan singkatan dari panoramic tomography yaitu merupakan suatu metode radiografi yang menghasilkan gambaran 
struktur fasial termasuk gigi-gigi rahang atas dan rahang bawah serta struktur jaringan penunjangnya. ${ }^{16,17}$ Radiografi panoramik biasa digunakan pada praktek ortodonti untuk mendapatkan informasi mengenai angulasi gigi, periode maturasi dan keadaan jaringan periodontal. ${ }^{18}$ Pemeriksaan angulasi gigi melalui radiografi panoramik sebaiknya dilakukan sebelum, selama dan setelah perawatan ortodonti untuk menilai kesejajaran akar. ${ }^{19}$

Keuntungan metode ini adalah dapat memperoleh gambaran anatomis yang cukup luas, dosis radiasi relatif rendah, pasien merasa nyaman disebabkan kecepatan paparan sinar $\mathrm{X}$ serta dapat dilakukan pada pasien yang terbatas atau sama sekali tidak dapat membuka mulut. Sedangkan kelemahan atau kekurangan dari pada teknik radiografi panoramik adalah detail anatomis tidaklah sejelas bila dibandingkan dengan radiografi intra oral periapikal. Kelemahan lain dari teknik ini adalah adanya pembesaran dan distorsi geometris serta gambaran tumpang tindih pada gigi-gigi terutama regio premolar. ${ }^{20,21,22}$

Berdasarkan latar belakang tersebut, maka penulis berkeinginan melakukan penelitian untuk mengetahui ada tidaknya perbedaan angulasi gigi pasca perawatan ortodonti pada kasus-kasus dengan pencabutan dan tanpa pencabutan pada pasien di Klinik Ortodonti RSGM FKG UI.

\section{Bahan Dan Cara Kerja}

Bahan dan alat penelitian adalah foto rontgen panoramik sesudah selesai perawatan ortodonti pada kasus dengan pencabutan dan tanpa pencabutan, penggaris busur, kertas tracing, viewer, pensil $3 \mathrm{H}$ dan program software komputer untuk pengolahan data.

Pada awalnya dilakukan pengambilan sampel yang memenuhi kriteria dari data rekam medik pasien yang telah selesai dirawat di Klinik Ortodonti RSGM FKG UI tahun 2001 sampai dengan 2005. Kriteria penerimaan subyek adalah pasien yang telah selesai dirawat ortodonti dengan alat cekat, baik dengan tindakan pencabutan (kedua premolar pertama pada rahang atas dan / atau rahang bawah) maupun tanpa tindakan pencabutan. Pasien dengan periode gigi permanen serta mempunyai foto panoramik setelah selesai perawatan ortodonti.

Setelah sampel didapat, kemudian dikelompokkan menjadi kelompok pencabutan dan tanpa pencabutan. Setelah itu dilakukan pengukuran angulasi gigi pada masing-masing foto panoramik.

Penelitian penilaian angulasi gigi ini dilakukan melalui radiografi panoramik. Referensi yang digunakan untuk menentukan besar derajat angulasi tiap gigi adalah sumbu panjang gigi dan garis referensi. Sumbu panjang gigi dengan akar tunggal didapat dari garis perpanjangan gambaran radiolusen dari saluran akar tunggal sedangkan sumbu panjang gigi premolar atas didapat dari garis pertengahan gambaran radiolusen akar mesial dan distal. Sumbu panjang gigi molar atas didapat dari garis perpanjangan gambaran radiolusen pada saluran akar palatal. Sumbu panjang gigi molar bawah didapat dari garis pertengahan gambaran radiolusen akar mesial dan distal. ${ }^{3}$

Sumbu panjang gigi tersebut ditarik sampai perpotongan dengan garis referensi. Untuk gigi-gigi rahang atas digunakan garis yang ditarik dari infra orbital kiri dan kanan. Titik infra orbital adalah titik paling bawah dari tulang orbital. Untuk gigi-gigi rahang bawah digunakan garis yang ditarik dari pusat foramen mental kiri dan kanan. Pusat foramen mental adalah titik pusat dari gambaran radiolusen foramen mental, yang umumnya terletak antara apeks akar gigi premolar pertama dan gigi premolar kedua (gambar 5). ${ }^{3}$

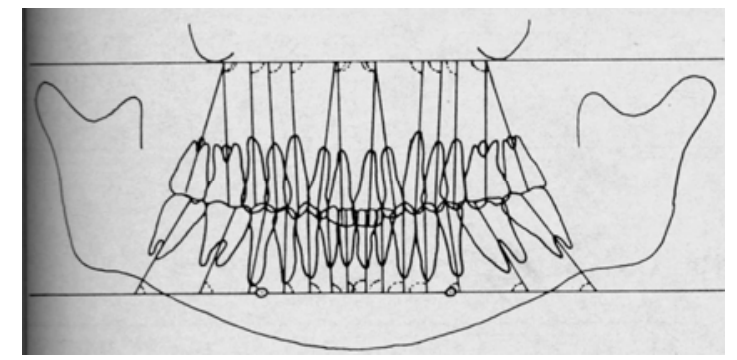

Gambar 5. Sudut-sudut angulasi yang diukur (Diambil dari Ursi ${ }^{3}$ ) 
Analisis statistik dilakukan setelah semua data didapat. Untuk mengetahui normalitas sebaran data dilakukan uji normalitas Shapiro Wilk. Analisis independent $t$ test digunakan untuk menguji perbedaan nilai rata-rata angulasi setiap gigi sesudah perawatan ortodonti antara kelompok pencabutan dan tanpa pencabutan baik pada rahang atas dan rahang bawah.

\section{Hasil}

Jumlah pasien yang selesai dirawat di Klinik Ortodonti RSGM FKG UI sejak bulan Januari 2001 - Desember 2005 adalah 110 orang. Dari jumlah tersebut yang memenuhi kriteria penelitian pada kelompok tanpa pencabutan sebanyak 28 sampel pada rahang atas dan 33 sampel pada rahang bawah. Sedangkan pada kelompok dengan pencabutan sebanyak 34 sampel pada rahang atas dan 15 sampel pada rahang bawah.
Analisis statistik deskriptif dilakukan untuk mendapatkan nilai rata-rata, simpangan baku, serta nilai maksimum dan minimum dari angulasi gigi setelah perawatan ortodonti dengan tindakan pencabutan dan tanpa pencabutan (tabel 3,4).Jika nilai rata-rata angulasi gigi lebih besar dari $90^{\circ}$ maka menunjukkan angulasi akar ke mesial atau membentuk sudut yang divergen terhadap bidang referensinya, sedangkan jika lebih kecil dari $90^{\circ}$ maka menunjukkan angulasi akar ke distal atau membentuk sudut yang konvergen terhadap bidang referensinya . Berdasarkan analisis perbedaan menggunakan independent $t$ test, ditemukan bahwa gigi premolar kedua kanan atas dan kaninus kiri atas serta gigi kaninus kanan bawah dan premolar kedua kiri bawah mempunyai nilai $\mathrm{p}<0,05$, hal ini menunjukkan terdapat perbedaan rata-rata angulasi gigi yang bermakna antara kelompok pencabutan dan tanpa pencabutan pada gigi tersebut (tabel 5 ).

Tabel 3. Nilai rata-rata, simpangan baku, serta nilai maksimum dan minimum angulasi gigi pasca perawatan ortodonti tanpa tindakan pencabutan

\begin{tabular}{|c|c|c|c|c|c|c|c|c|c|c|c|c|c|c|}
\hline Gigi & 17 & 16 & 15 & 14 & 13 & 12 & 11 & 21 & 22 & 23 & 24 & 25 & 26 & 27 \\
\hline $\mathrm{N}$ & 28.00 & 28.00 & 28.00 & 28.00 & 28.00 & 28.00 & 28.00 & 28.00 & 28.00 & 28.00 & 28.00 & 28.00 & 28.00 & 28.00 \\
\hline $\operatorname{Mean}\left({ }^{\circ}\right)$ & 102.25 & 96.43 & 95.32 & 93.07 & 93.04 & 90.54 & 90.11 & 90.43 & 92.25 & 93.43 & 94.11 & 94.57 & 95.32 & 103.89 \\
\hline S.D. $\left({ }^{\circ}\right)$ & 3.81 & 2.48 & 2.81 & 2.53 & 2.47 & 2.28 & 2.26 & 2.55 & 2.68 & 2.42 & 2.20 & 2.37 & 2.79 & 3.78 \\
\hline $\operatorname{Min}\left({ }^{\circ}\right)$ & 96.00 & 90.00 & 91.00 & 89.00 & 89.00 & 86.00 & 84.00 & 86.00 & 87.00 & 90.00 & 89.00 & 90.00 & 90.00 & 95.00 \\
\hline $\operatorname{Max}(0)$ & 112.00 & 101.00 & 102.00 & 99.00 & 99.00 & 95.00 & 94.00 & 96.00 & 98.00 & 100.00 & 99.00 & 100.00 & 102.00 & 115.00 \\
\hline Gigi & 47 & 46 & 45 & 44 & 43 & 42 & 41 & 31 & 32 & 33 & 34 & 35 & 36 & 37 \\
\hline $\mathrm{N}$ & 33.00 & 33.00 & 33.00 & 33.00 & 33.00 & 33.00 & 33.00 & 33.00 & 33.00 & 33.00 & 33.00 & 33.00 & 33.00 & 33.00 \\
\hline $\operatorname{Mean}\left({ }^{\circ}\right)$ & 65.55 & 72.27 & 78.67 & 81.12 & 86.52 & 90.18 & 91.42 & 92.03 & 90.18 & 85.94 & 83.09 & 78.48 & 71.97 & 65.79 \\
\hline S.D. $\left({ }^{\circ}\right)$ & 4.73 & 2.76 & 3.88 & 3.25 & 3.12 & 2.88 & 2.34 & 2.59 & 3.25 & 3.92 & 3.72 & 3.34 & 3.77 & 4.85 \\
\hline $\operatorname{Min}\left({ }^{\circ}\right)$ & 55.00 & 65.00 & 68.00 & 73.00 & 80.00 & 82.00 & 86.00 & 87.00 & 80.00 & 74.00 & 74.00 & 70.00 & 63.00 & 56.00 \\
\hline $\operatorname{Max}\left(\left(^{\circ}\right)\right.$ & 74.00 & 78.00 & 87.00 & 86.00 & 92.00 & 95.00 & 96.00 & 96.00 & 96.00 & 92.00 & 90.00 & 84.00 & 83.00 & 78.00 \\
\hline
\end{tabular}


Tabel 4. Nilai rata-rata, simpangan baku, serta nilai maksimum dan minimum angulasi gigi pasca perawatan ortodonti dengan tindakan pencabutan.

\begin{tabular}{lcccccc|cccccc}
\hline Gigi & 17 & 16 & 15 & 13 & 12 & 11 & 21 & 22 & 23 & 25 & 26 & 27 \\
\hline $\mathrm{N}$ & 34.00 & 34.00 & 34.00 & 34.00 & 34.00 & 34.00 & 34.00 & 34.00 & 34.00 & 34.00 & 34.00 & 34.00 \\
$\operatorname{Mean}\left({ }^{\circ}\right)$ & 101.06 & 95.32 & 92.35 & 94.15 & 91.32 & 90.62 & 91.29 & 93.09 & 94.94 & 93.32 & 94.85 & 102.06 \\
$\mathrm{SD}\left({ }^{\circ}\right)$ & 4.87 & 4.04 & 5.61 & 2.89 & 2.40 & 1.65 & 1.88 & 1.96 & 2.43 & 3.96 & 4.81 & 4.36 \\
$\operatorname{Min}\left({ }^{\circ}\right)$ & 94.00 & 87.00 & 80.00 & 89.00 & 87.00 & 87.00 & 87.00 & 90.00 & 89.00 & 85.00 & 81.00 & 96.00 \\
$\operatorname{Max}\left({ }^{\circ}\right)$ & 110.00 & 104.00 & 106.00 & 100.00 & 97.00 & 94.00 & 96.00 & 98.00 & 100.00 & 103.00 & 106.00 & 112.00 \\
\hline $\operatorname{Gigi}$ & 47 & 46 & 45 & 43 & 42 & 41 & 31 & 32 & 33 & 35 & 36 & 37 \\
\hline $\mathrm{N}$ & 15.00 & 15.00 & 15.00 & 15.00 & 15.00 & 15.00 & 15.00 & 15.00 & 15.00 & 15.00 & 15.00 & 15.00 \\
$\operatorname{Mean}\left({ }^{\circ}\right)$ & 64.07 & 71.47 & 77.07 & 84.00 & 90.40 & 90.93 & 91.13 & 90.47 & 83.73 & 75.87 & 70.47 & 65.13 \\
$\operatorname{SD}\left({ }^{\circ}\right)$ & 4.68 & 3.09 & 2.08 & 2.29 & 2.38 & 2.63 & 2.26 & 2.13 & 2.89 & 1.95 & 3.09 & 4.56 \\
$\operatorname{Min}\left({ }^{\circ}\right)$ & 55.00 & 67.00 & 72.00 & 78.00 & 86.00 & 86.00 & 87.00 & 85.00 & 77.00 & 71.00 & 63.00 & 58.00 \\
$\operatorname{Max}\left({ }^{\circ}\right)$ & 70.00 & 77.00 & 80.00 & 87.00 & 95.00 & 96.00 & 96.00 & 94.00 & 87.00 & 80.00 & 76.00 & 74.00 \\
\hline
\end{tabular}

Tabel 5. Hasil uji independent $t$ test untuk menguji perbedaan nilai rata-rata angulasi gigi pasca perawatan ortodonti antara kasus pencabutan dan tanpa pencabutan.

\begin{tabular}{|c|c|c|c|c|c|c|c|c|c|c|c|c|c|c|}
\hline Gigi & 17 & 16 & 15 & 14 & 13 & 12 & 11 & 21 & 22 & 23 & 24 & 25 & 26 & 27 \\
\hline $\begin{array}{l}\text { Mean } \\
\mathrm{NE}\left({ }^{\circ}\right)\end{array}$ & 102.25 & 96.43 & 95.32 & 93.07 & 93.04 & 90.54 & 90.11 & 90.43 & 92.25 & 93.43 & 94.11 & 94.57 & 95.32 & 103.89 \\
\hline $\begin{array}{l}\text { Mean } \\
\mathrm{E}\left({ }^{\circ}\right)\end{array}$ & 101.06 & 95.32 & 92.35 & & 94.15 & 91.32 & 90.62 & 91.29 & 93.09 & 94.94 & & 93.32 & 94.85 & 102.06 \\
\hline $\begin{array}{c}\text { Mean } \\
\operatorname{Diff}\left({ }^{\circ}\right)\end{array}$ & 1.19 & 1.11 & 2.97 & & -1.11 & -0.79 & -0.51 & -0.87 & -0.84 & -1.51 & & 1.25 & 0.47 & 1.83 \\
\hline $\mathrm{p}$ & 0.30 & 0.21 & $0.01 *$ & & 0.11 & 0.20 & 0.31 & 0.13 & 0.16 & $0.02 *$ & & 0.15 & 0.65 & 0.09 \\
\hline Gigi & 47 & 46 & 45 & 44 & 43 & 42 & 41 & 31 & 32 & 33 & 34 & 35 & 36 & 37 \\
\hline $\begin{array}{l}\text { Mean } \\
\text { NE( }\left(^{\circ}\right)\end{array}$ & 65.55 & 72.27 & 78.67 & 81.12 & 86.52 & 90.18 & 91.42 & 92.03 & 90.18 & 85.94 & 83.09 & 78.48 & 71.97 & 65.79 \\
\hline $\begin{array}{c}\text { Mean } \\
\mathrm{E}\left({ }^{\circ}\right)\end{array}$ & 64.07 & 71.47 & 77.07 & & 84.00 & 90.40 & 90.93 & 91.13 & 90.47 & 83.73 & & 75.87 & 70.47 & 65.13 \\
\hline $\begin{array}{l}\text { Mean } \\
\operatorname{Diff}\left({ }^{\circ}\right)\end{array}$ & 1.48 & 0.81 & 1.60 & & 2.52 & -0.22 & 0.49 & 0.90 & -0.28 & 2.21 & & 2.62 & 1.50 & 0.65 \\
\hline $\mathrm{p}$ & 0.32 & 0.37 & 0.14 & & $0.01 *$ & 0.80 & 0.52 & 0.26 & 0.76 & 0.06 & & $0.01 *$ & 0.19 & 0.66 \\
\hline
\end{tabular}

* Secara statistik menunjukkan perbedaan yang bermakna, dengan nilai $\mathbf{p}<0,05$

\section{Pembahasan}

Berdasarkan database di Klinik Ortodonti RSGM FKG UI, jumlah pasien yang telah selesai dirawat ortodonti sejak bulan Januari 2001 - Desember 2005 adalah 110 orang. Dari jumlah tersebut yang memenuhi syarat sebagai sampel penelitian pada kelompok tanpa pencabutan sebanyak 28 sampel pada rahang atas dan 33 sampel pada rahang bawah. Sedangkan pada kelompok dengan pencabutan sebanyak 34 sampel pada rahang atas dan 15 sampel pada rahang bawah. Jumlah sampel tidak dapat mencapai keseluruhan subjek yang telah selesai dirawat ortodonti ini disebabkan tidak lengkapnya foto panoramik setelah perawatan ortodonti dan ada yang tidak memenuhi kriteria seperti adanya pencabutan gigi molar, premolar kedua atau insisif, sehingga jumlah sampel mengecil

Terlihat bahwa secara umum gambaran nilai rata-rata angulasi gigi rahang atas setelah perawatan ortodonti tanpa tindakan pencabutan adalah gigi insisif relatif tegak dan berangsur- 
angsur semakin divergen terhadap bidang infra orbital dari gigi kaninus hingga molar kedua. Untuk gigi-gigi bawah, menunjukkan angulasi gigi-gigi insisif yang relatif tegak. Sedangkan angulasi gigi kaninus, premolar pertama, premolar kedua, molar pertama dan molar kedua terlihat memberikan gambaran sudut yang berangsur-angsur semakin konvergen terhadap foramen mentale. Gambaran tersebut mempunyai pola kemiringan gigi yang sama dengan penelitian angulasi gigi pada oklusi normal yang dilakukan oleh Ursi dan kawankawan serta penelitian Wijayani dengan nilai angulasi rata-rata yang tidak jauh berbeda dari penelitian ini. Hal ini mungkin disebabkan karena pada kasus-kasus tanpa pencabutan biasanya lebih sederhana. Dengan demikian perbaikan yang dilakukan pada umumnya tidak membutuhkan pergerakan gigi yang jauh, sehingga tidak membutuhkan perbaikan angulasi gigi yang besar pasca perawatan ortodonti. $^{7}$

Pada kelompok dengan tindakan pencabutan terlihat bahwa secara umum pola gambaran angulasi gigi-gigi yang relatif sama dengan kelompok tanpa pencabutan, kecuali gigi kaninus lebih divergen dari premolar kedua rahang atas. Hal ini mungkin disebabkan pada kasus dengan tindakan pencabutan premolar pertama, pergerakan gigi kaninus dan premolar kedua lebih jauh dari pada kasus tanpa pencabutan sehingga lebih sulit mencapai angulasi gigi ideal pasca perawatan ortodonti.

Berdasarkan hasil analisis perbedaan yang menggunakan independent $t$ test untuk menguji perbedaan angulasi gigi pasca perawatan ortodonti antara tindakan pencabutan dan tanpa pencabutan, terdapat perbedaan bermakna pada gigi premolar kedua kanan dan kaninus kiri rahang atas. Sedangkan pada rahang bawah terdapat perbedaan bermakna pada gigi kaninus kanan dan premolar kedua kiri.

Menurut Nanda (2005), pada hasil akhir perawatan kasus dengan tindakan pencabutan, sering kali ditemukan masalah pada kesejajaran akar pada insisif kedua atas, premolar bawah dan gigi yang berdekatan dengan tempat ekstraksi. Hal ini merupakan manifestasi yang sering terjadi akibat kegagalan memperbaiki angulasi gigi pada tahap finishing. ${ }^{5}$

Nanda (1993) menyimpulkan bahwa ada 10 kriteria yang harus dipenuhi sebelum retensi, salah satunya adalah kesejajaran akar pada daerah dekat tempat pencabutan. ${ }^{4}$ Oleh karena itu, khususnya pada kasus dengan pencabutan perlu dilakukan evaluasi kesejajaran akar sebelum tahap finishing, sehingga angulasi gigi yang belum sesuai dapat diperbaiki dengan melakukan second order bend terutama di daerah dekat tempat pencabutan.

Blake dan kawan-kawan

menyatakan salah satu faktor yang mempengaruhi stabilitas hasil perawatan adalah kesejajaran akar. $^{2}$ Untuk mendapatkan hasil perawatan yang stabil diperlukan angulasi gigi yang baik sehingga dapat mendistribusikan gaya oklusal secara proporsional pada tiap titik kontak gigi. $^{3}$

\section{Kesimpulan}

Berdasarkan hasil penelitian ini dapat disimpulkan bahwa secara umum gambaran nilai rata-rata angulasi gigi pasca perawatan ortodonti tanpa tindakan pencabutan pada rahang atas adalah gigi insisif relatif tegak dan berangsur-angsur semakin divergen dari gigi kaninus hingga molar kedua terhadap bidang referensi infra orbitale. Untuk gigi-gigi pada rahang bawah, menunjukkan angulasi gigi insisif yang relatif tegak. Sedangkan angulasi gigi kaninus, premolar pertama, premolar kedua, molar pertama dan molar kedua rahang bawah terlihat memberikan gambaran sudut yang berangsur-angsur semakin konvergen terhadap bidang referensi foramen mentale.

Pada kasus dengan tindakan pencabutan, terlihat bahwa secara umum angulasi gigi pasca perawatan ortodonti mempunyai pola gambaran angulasi gigi-gigi rahang atas dan bawah yang relatif sama dengan kasus tanpa pencabutan, kecuali pada gigi kaninus dan premolar kedua.

Terdapat perbedaan bermakna secara statistik antara angulasi gigi pasca perawatan ortodonti dengan tindakan pencabutan dan tanpa 
pencabutan pada gigi premolar kedua kanan dan kaninus kiri rahang atas serta gigi kaninus kanan dan premolar kedua kiri rahang bawah, sedangkan pada gigi-gigi yang lain tidak terdapat perbedaan.

Hasil penelitian ini menunjukkan bahwa pada kelompok tanpa pencabutan didapat nilai rata-rata angulasi gigi yang menyerupai nilai rata-rata angulasi gigi dengan oklusi normal, sehingga diharapkan mempunyai stabilitas yang lebih baik dalam arah sagital. Di pihak lain, kasus dengan pencabutan didapat perbedaan angulasi di daerah dekat tempat pencabutan yaitu pada gigi kaninus dan premolar kedua, sehingga perlu dilakukan tindakan antisipasi untuk lebih meningkatkan stabilitas pasca perawatan ortodonti.

\section{Daftar Pustaka}

1. Proffit WR. Contemporary Orhodontics. $3^{\text {rd }}$ Ed. St. Louis. Mosby. 2000: 128-141.

2. Blake M, Bibby K. Retention and Stability: A review of literature. Am J Orthod. 1998; 114: 299-306.

3. Ursi WJS. Assesment of Mesiodistal Axial Inclination through Panoramic Radiography. JCO. 1990; vol.XXIV no.3: 166-173.

4. Nanda R, Burstone CJ. Retention and Stability in Orthodontics. WB Saunders Company.1993: 98-99.

5. Nanda R. Biomechanics and Esthetic Strategies in Clinical Orthodontics. Elsevier Saunders Inc. 2005: 340-341.

6. Andrews LF. The Six Key to Normal Occlusion. Am. J. Orthod. 1972; 62: 296-309.

7. Wijayani NW. Nilai Angulasi Mesio Distal Gigi-Gigi Orang Indonesia Dengan Oklusi Normal. Laporan Hasil Penelitian FKG UI. 1998: 29-36.

8. Krisnawati. Kecenderungan Perawatan Ortodonti dengan Pencabutan Gigi Ditinjau dari Faktor Usia, Jenis kelamin dan Maloklusi. J Kedokteran gigi UGM. Yogyakarta. 1996: 3240.
9. Vaden JL, Kiser HE. Straight Talk About Extraction And Non Extraction: A Differential Diagnosis Decision. Am J Orthod. 1996; 109: 445-452.

10. Basciftci FA, Usumez S. Effects of Extraction and Non Extraction Treatment on Class I and Class II Subjects. Angle Orthod. 2003; 73: 3642.

11. Poling R. A Method of Finishing the Occlusion. Am J Orthod. 1999; Vol 115: 476-487.

12. Tulin J. Normal Faciolingual of Tooth Crowns Compared with Treatment Group Standard and Pretorque Bracket. Am. J. Orthod. 1997; 112: 50-57.

13. Carlson SK, Johnson E. Bracket Positioning and Resets: Five Steps to Align Crowns and Roots Concistently. Am. J. Orthod. January 2001; Vol. 117: 76-80.

14. Nanda R. Biomechanics in Clinical Orthodontics. Philadelphia: WB. Saunders. 1997; 9: 156-187.

15. Langland OE, Langlais RP. Principles and Practise of Panoramic Radiology.

16. Mckee, Ian W, Glover, Kenneth E. The Effect of Vertical and Horizontal Head Positioning in Panoramic Radiography on Mesiodistal Tooth Angulations. The angle Orthodontist. vol.71, no.6: 442-451.

17. Ackam MO, Altiok T, Ozdiler E. Panoramic radiographs: A Tool for Investigating Skeletal Pattern. Am. J. Orthod. February 2003; vol. 123: 175-181.

18. Lee J. The Effects of Buccolingual Root Torque on the Appearance of Root Angulation on Panoramic Radiographs. Am. J. Orthod. March 2005; vol. 127: 393.

19. Larheim TA, Svanes DB, Johannnessen S. Reproducibility Rotational Panoramic Radiography: Mandibular Linear Dimension and Angles. Am. J. Orthod. 1986; 90: 45-51.

20. Mckee IW, Williamson PC. The Accuracy of 4 Panoramic Units in the Projection of Mesiodistal Tooth Angulations. Am. J. Orthod. February 2002; vol.121:166-175.

21. Lucchesi MV, Wood RE. Suitability of Panoramic Radiograph for Assessment of Mesiodistal Angulation of Teeth in the Buccal Segments of Mandible. Am. J. Orthod.October 1988; vol. 94: 303-310. 